\title{
CHILOÉ, EL LABERINTO DESCONOCIDO
}

\author{
Juan Manuel Vial \\ Crítico literario
}

RESUMEN: El interés que en los últimos años ha despertado Chiloé entre los chilenos del continente se restringe al turismo, a cierta visión folclorizante y a eventuales apariciones del archipiélago en la coyuntura noticiosa. Pero, en rigor, es poco lo que sabemos de la singular historia de una zona descrita por Benjamín Subercaseaux como "un extraordinario laberinto". Este ensayo sondea algunas memorias y fuentes literarias con el fin de mitigar, en parte al menos, el desconocimiento que envuelve a Chiloé.

Palabras clave: Chiloé, John Byron, Benjamín Subercaseaux, Recta Provincia, brujos, finis terrae.

\section{CHILOE, THE UNDISCOVERED LABYRINTH}

ABstract: The attention paid by the inhabitants of continental Chile to Chiloe in recent years has been confined to tourism, a vague interest in its folklore and occasional stories about the archipelago in the media. Really, though, we know very little about the remarkable history of an area described by Benjamin Subercaseaux as "an extraordinary labyrinth". This essay explores some memories and literary sources with a view to alleviating, at least in part, the ignorance surrounding Chiloe.

Keywords: Chiloe, John Byron, Benjamín Subercaseaux, Recta Provincia, sorcerers, finis terrae.

Juan Manuel Vial. Periodista, crítico literario y traductor. Columnista de La Tercera.Email: vialjuanmanuel@gmail.com. 
ospecho que la efímera actualidad que cobró Chiloé en la prensa
nacional a mediados de 2016 no bastó para que los norteños nos interesáramos mayormente por un territorio que a lo lejos se percibe ajeno, misterioso o, en el mejor de los casos, folclorizado a más no poder. Lo que ocurra o deje de ocurrir en Chiloé - o lo que históricamente ha ocurrido con el transcurso de los siglos - nos tiene sin mayor cuidado. Pero hace dos años, la Isla Grande de Chiloé ardía en llamas. Todo comenzó un 1 de mayo con una serie de protestas sociales que mantuvieron a los chilotes en pie de guerra por casi tres semanas. Los manifestantes le exigían al gobierno medidas de socorro ante la inusual persistencia de la marea roja, un envenenamiento natural de moluscos que puede ser mortal para el hombre y que, en rigor, no es ni marea ni roja. Las imágenes que generó el fenómeno tóxico, considerado el peor de la historia, fueron en muchos sentidos apocalípticas: la estatua de la Pincoya ubicada al centro de la plaza de Castro apareció cubierta de pintura negra, los caminos quedaron cortados por innumerables barricadas ardientes y el desabastecimiento llegó a ser algo más que una amenaza. Millones de machas (Mesodesma donacium) vararon a lo largo de seis kilómetros de costa y salió a la luz un hecho que alertó a los medioambientalistas, $\mathrm{y}$, de paso, esbozó el rostro de un culpable ante la violencia de la marea roja: en marzo de 2016, las autoridades navales dieron autorización para que algunos productores de salmón se deshicieran de nueve mil toneladas de pescados muertos en el mar de Chiloé. Dentro del imaginario colectivo, los desechos - podridos y contaminados con químicos — pasaron a ser los causantes de la feroz irrupción de la marea roja. Por su parte, la industria salmonera, que por tres décadas ha sido una fuerte proveedora de empleos en la región, venía pagando desde hacía un tiempo el precio de la codicia: muchas plantas han cerrado sus faenas debido a la sobreexplotación y cualquiera que haya navegado por la zona en los últimos 20 años — la belleza de los mares de Chiloé es reconocida por los veleristas de todo el mundoha podido comprobar que la depredación del paisaje chilote es en buena medida culpa suya. Las jaulas de salmones abandonadas son un peligro constante para quienes surcan esas aguas y una evidencia ostentosa de la explotación irresponsable.

Hace dos años, entonces, por medio de los encendidos reportes que varias veces al día transmitían los noticieros de televisión, los santia- 
guinos volvimos a oír de Chiloé. ¿Habremos entendido realmente algo de lo que allá ocurría? No olvidemos que esa misma televisión nos ha venido entregando por décadas una versión dislocada del archipiélago. Es lo que sostienen, valiéndose de cierta tarabilla, Mauricio Marino y Cipriano Osorio en Juicio a los brujos de Chiloé, libro en el que ya me detendré con mayor detalle:

Si observamos, por ejemplo, los canales nacionales de televisión, podemos constatar en forma reiterada la folclorización exótica de la sociedad y cultura chilota. Desde las telenovelas de ficción hasta las presentaciones estereotipadas de la música insular para la exportación; se muestra un Chiloé fantástico, lleno de magia en un contexto de vida apacible, tranquila, con aires tradicionales y costumbristas que de seguro a cualquier persona (que lo ve por televisión) lo "atrapa", al punto que tiene ganas de conocerlo. Es una burda distorsión fuera de contexto que se ha hecho de la cultura insular, la "vedette cultural" de los últimos años; para satisfacer el deseo de conocer lo exótico, autóctono, mistico, folclórico, etc. que muestra la televisión. Y si visitan Chiloé (turisteando), promovido por la televisión y el turismo, esperan que alguna familia chilota los invite a un curanto típico (como en la "tele"). Y lo máximo del folclorismo exótico sería tener la suerte de ver al Camahueto o acercarse y conocer alguna experiencia con brujos. Ni siquiera se muestra algún aspecto de la realidad con todos sus ingredientes. Pareciera que en Chiloé no hay problemas, no hay conflictos sociales, económicos, de identidad. Pareciera que en esta sociedad no hay necesidades, demandas, injusticia, explotación, discriminación, etc. Entonces: ¿de qué cultura chilota hablamos?, ¿la que nos muestra la televisión?, ¿aquella que recorremos "con aires mágicos", como turistas? No cabe duda alguna de que avanzamos en la dominación sobre Chiloé consumiendo esta "puesta en escena recortada", ya sea virtual o físicamente, a lo cual el isleño debe responder porque su situación de dependencia y dominado no le ofrece muchas alternativas. ${ }^{1}$

En Chile o una loca geografía, aquel libro provocador, cómico, inteligente, que fue publicado en 1940 y reeditado sucesivamente a lo

${ }^{1}$ Mauricio Marino y Cipriano Osorio, Juicio a los brujos de Chiloé (Santiago: Ediciones Tácitas, 2014), 212-13. 
largo de décadas, Benjamín Subercaseaux se admira de que Chiloé sea un lugar desconocido para los chilenos, quienes, "al avanzar hacia el sur y colonizar tan apartadas regiones como Aysén, Chile Chico, Última Esperanza y hasta la misma isla de Navarino, en el Beagle, olvidaron que, a un paso de Puerto Montt, se extendía una isla inmensa y casi virgen". ${ }^{2}$ Subercaseaux no ahonda en el hecho de que algunos de los confines que menciona fueron colonizados precisamente por nativos de Chiloé, pero su autoridad en cuanto a temas chilotes no flaquea por ello, ya que no sólo vivió en la Isla Grande (coincidentemente, parte de Chile o una loca geografía fue escrita en Tenaún, a unos cuarenta kilómetros de Dalcahue, en una casona imponente que hace poco fue rescatada de la ruina), sino que además navegó esos mares en su propio yate, y ésa, basta ojear un mapa para entender por qué, es la mejor manera de recorrer latitudes en las que "el geógrafo más notable no podrá retener ni siquiera una parte de este extraordinario laberinto". ${ }^{3}$ Nomás cruzar el canal de Chacao, advierte Subercaseaux, uno deja atrás "ese Chile tradicional y su modorra irresponsable": por delante está "la tierra heroica, aquella que recibió más barcos exploradores que ninguna otra en el mundo". 4

El escritor estima que el desdén de los continentales por el archipiélago viene de antiguo, partiendo por los propios conquistadores, que miraron con sospecha esa tierra de bosques cerrados y amenazantes: "España no es un país arbolado ni gustan los españoles de esas complicaciones. Prefirieron, pues, el Chile central y llano". ${ }^{5}$ No obstante, entre los que se animaron a cruzar el canal de Chacao figuró nada menos que Alonso de Ercilla, "el primer poeta joven de Chile" según el decir de Enrique Lihn. A mediados del siglo XVI, Ercilla talló en un árbol parte de su experiencia chilota, o al menos es lo que asegura en unos famosos versos de La Araucana:

Pero yo, por cumplir el apetito, que era poner el pie más adelante, fingiendo que marcaba aquel distrito,

2 Benjamín Subercaseaux, Chile o una loca geografía (Santiago: Editorial Universitaria, 2010), 243-44.

${ }^{3}$ Ibídem, 239.

${ }^{4}$ Ibídem, 239-40.

${ }^{5}$ Ibídem, 245. 
cosa al descubridor siempre importante, corrí una media milla, do un escrito quise dejar para señal bastante; y en el tronco que vi de más grandeza escribí con un cuchillo en la corteza:

Aquí llegó, donde otro no ha llegado, don Alonso de Ercilla, que el primero, en un pequeño barco deslastrado, con solo diez pasó el desaguadero, el año de cincuenta y ocho entrado sobre mil quinientos, por febrero, a las dos de la tarde, al postrer día, volviendo a la dejada compañía. ${ }^{6}$

Cuatro siglos más tarde, otros dos poetas jóvenes, montados esta vez sobre sus correspondientes mampatos, cabalgaban por Chiloé en el mismo mes que lo hizo Ercilla. Así lo cuenta Luis Oyarzún en Diario intimo:

Me asalta una visión de hace cinco años [1945]. Iba una tarde de febrero con Nicanor Parra en un paseo a caballo por Cucao, al oeste de la Isla Grande de Chiloé, y subíamos por un caminillo entre unos espesos bosques. Había llovido continuamente los días anteriores y el aire era impecable. Nos envolvía el olor de la madera viva y de las hojas que se pudrían en el suelo espeso. De pronto llegamos a la cumbre de la colina y vimos una pequeña bahía de mar tranquilo enmarcada por la selva, como un lago. Permanecimos un rato admirados y a mí me hizo bien contemplar esas dulces aguas después de haber visto y escuchado a las desgarradas olas que cubren de espuma a las rocas en forma de ídolos enormes de la gran playa cubierta de pangues inmensos, de tallos animales, amoratados. ${ }^{7}$

Subercaseaux fue un tipo dado a la libre especulación, en parte gracias al entrenamiento como psicólogo, antropólogo y sociólogo que ad-

\footnotetext{
${ }^{6}$ Alonso de Ercilla, La Araucana (Santiago: Pehuén, 2001), 355.

${ }^{7}$ Luis Oyarzún, Diario intimo (Valparaíso: Editorial de la Universidad de Valparaíso, 2017), 39.
} 
quirió de joven en La Sorbonne. No ha de extrañar que, por lo mismo, arriesgue una hipótesis acerca del origen del mampato, teoría que suena bastante sensata: "Las pobres cabalgaduras, ellas, se fueron a nado por esas aguas heladas. Tal vez por eso los caballos chilotes se quedaron tan pequeños y ateridos". ${ }^{8}$ Para establecerse en Chiloé, continúa,

...los españoles pusieron en práctica su viejo sistema del despojo y del menor esfuerzo, propio de visigodos y germanos, apropiándose de los pocos terrenos clareados que los indios cultivaban (...). Allí vegetaron, sin avanzar al interior, vecinos al mar, que es llano y generoso en alimentos. Sólo la visita de los piratas vino a perturbar más tarde esa paz idílica. Los holandeses, sobre todo, que permanecieron un buen tiempo en algunas partes de la isla, y les legaron, junto con algunas cabelleras rubias, la leyenda del barco fantasma (aquí se llamó Caleuche). ${ }^{9}$

A través de un párrafo revelador en su recorrido por Chile y su alocada geografía, Subercaseaux articula toda la admiración que le provoca el pueblo chilote, pueblo al que considera excepcional ya que en nada se asemeja al resto del país:

Chiloé - ignoro cuál sea la etimología de este nombre - parece ser un Chile aparte, algo esencialmente diferente a lo que hemos visto hasta aquí. Sus indios tienen un marcado tipo polinésico: son bajos, robustos, relevados de pecho y cortos de cuello. Su carácter suave y dócil. Muchos se mezclaron a los españoles, de manera que hoy día podemos hablar de un tipo chilote: bajito, activo, sonriente, buen marino y amigo de la paz, una especie de indonesio que, a mi modo de ver, es lo mejor que tenemos en materia de raza homogénea, moral y eficiente. ¡Qué agradable país sería el Chile central si estuviera poblado solamente por chilotes! $!^{10}$

Pero el Estado chileno, siempre tan absorto en su propio ombligo, no les dio la debida protección a los habitantes del archipiélago, y Subercaseaux denuncia el abandono y la distancia que en su momento percibió:

\footnotetext{
${ }^{8}$ Subercaseaux, Una loca geografia, 245.

${ }^{9}$ Ibídem.

${ }^{10}$ Ibídem, 246.
} 
Chiloé ha pasado a ser el "finis terrae" de Chile. Nadie se ocupa de los admirables esfuerzos de esta gente para subsistir. Cuando se les incendia alguna ciudad $-\mathrm{y}$ esto ocurre a menudo- las autoridades les envían alimentos y vestuarios en avión, como si fueran una colonia penal... lo demás queda a cargo del chilote. Recordemos, como un ejemplo, que el primer camino que unió Ancud y Castro fue labrado en la selva por un indio: Caicumeo. El gobierno lo premió dándole tierras; esto es, más selva que clarear a golpes de hacha. ${ }^{11}$

\section{LA DESIDIA ANTE EL OCÉANO}

A lo largo de los siglos, el archipiélago ha tenido un devenir histórico diferente al resto del territorio, partiendo por dos peculiaridades. La primera es que Chiloé siguió siendo leal a la corona española hasta 1826; o sea, por un lapso de ocho años luego de declarada la independencia (por aquella época, y durante las décadas que siguieron, los isleños se mostraron renuentes a aceptar el nuevo orden republicano). La segunda alude a que allá el mar forja la rutina diaria y el carácter de los habitantes, como en ningún otro lugar de Chile. Y aquí vale la pena detenernos un poco, ya que cada vez que los chilenos aseguramos ser un "país marino", no estamos siendo lo suficientemente rigurosos. Marino y Osorio profundizan en este punto e informan que la mayoría de las actividades cotidianas de los chilotes se realizan en torno a lo que denominan bordemar. No ha de extrañar, por lo tanto, que la densidad poblacional más alta de Chiloé corresponda a las zonas costeras. En el bordemar se habita y allí se efectúan las actividades de recolección, pesca, horticultura y ganadería menor; allí también se fabrican las embarcaciones; las orillas son un centro de intercambio comercial, e inicio y término de la ruta de canales interiores del archipiélago. En el bordemar se construyen capillas e iglesias y se manifiesta la religiosidad popular. En suma, hablamos del lugar en donde el chilote logra la mayor optimización de su reproducción económica, social y cultural. ${ }^{12}$

Cuando Joaquín Edwards Bello denunció el proverbial desinterés que el chileno ha demostrado por el mar, no se refería, por supuesto,

\footnotetext{
${ }^{11}$ Ibídem.

${ }^{12}$ Marino y Osorio, Juicio a los brujos, 200-01.
} 
al chilote, el único poblador de un país costero que merece llamarse marino con propiedad. Edwards Bello ilustró su certera observación valiéndose de la estatua de Arturo Prat ubicada en la Plaza Sotomayor de Valparaíso, frente a la Comandancia en Jefe de la Armada. Incomprensiblemente, el prócer figura mirando al cerro, de espalda al mar. Chile, concluyó el escritor, le ha dado históricamente la espalda al Océano Pacífico. Y los porteños, agrega Subercaseaux, "al mar no lo miran jamás". ${ }^{13}$ Este hecho vendría a ser "una confirmación fortuita de una impresión que me deja el chileno: la de ser un marino por fuerza, sin ninguna vocación para el mar". ${ }^{14}$ Años atrás oí en la radio a un experto en temas navales, ex marino, quejarse de que la escuadra chilena se movía en conjunto sólo 24 días al año. Por su parte, el chilote desciende de los pueblos de canoeros que por miles de años navegaron los furiosos y gélidos mares australes. Y como tal pudo emprender una hazaña mayor: la colonización de la Patagonia chilena y argentina durante los siglos XIX y XX. El lanchón chilote jugó un rol crucial en tal cometido y sigue siendo un símbolo flotante, mecánicamente perfecto, del temple del isleño.

En su famoso prólogo a Chile o una loca geografia, Gabriela Mistral hermana a Subercaseaux con Edwards Bello: "Mucho me temo que haga compañía en su soledad magnífica al bueno de Joaquín Edwards Bello, gran descontento en cuanto a gran exigidor de la chilenidad". ${ }^{15}$ Allí mismo, la Mistral le traspasó el mote de "tábano" a Edwards Bello, aludiendo al sobrenombre que recibió Sócrates gracias a su capacidad de hostigar a las masas. "Ahora va usted a sentarse bajo el mismo árbol del apóstol zumbón", le advierte a Subercaseaux. "No le envidio la tormenta, pues habiendo picado sólo de paso al Buey Apis de la pedagogía criolla, yo saqué de mi ocurrencia varias lastimaduras... Pero, ¿dónde iríamos a parar si viviésemos atollados en el plasma oleaginoso de la complacencia o acabásemos por asfixiarnos, embetunados en la glosura pegajosa que es la autoadulación patriotera?". ${ }^{16}$

Más allá de denunciar la desidia del chileno ante sus mares, Subercaseaux promueve el amor al océano valiéndose, a veces, de imágenes

\footnotetext{
${ }^{13}$ Subercaseaux, Una loca geografia, 142.

${ }^{14}$ Ibídem, 146.

15 Ibídem, 22-23.

${ }^{16}$ Ibídem, 23.
} 
hermosas, de ciertos raptos poéticos y del vocabulario propio de la arenga:

Porque jamás he visto otra bandera que diga tanto de mares y de barcos como la nuestra. Hay un no sé qué en su estrella blanca, en el azul profundo y el rojo, que se destacan en forma tan limpia sobre la transparencia del cielo y del mar. Se diría que esta bandera huele a espumas, a cuello fresco y almidonado de marineros, a lienza inmaculada. No hay nada más "naval" que nuestro pabellón. Yo lo siento así. En tierra, lo veo sucio y colgante: un marino triste que no sabe qué hacer entre el polvo y la verdura. La bandera de Chile no quiere saber del verde, sino del azul. Quizá si este capítulo lo he escrito con el solo fin de hacerlo comprender a los jóvenes de tierra adentro: nuestra bandera ha nacido para los latigazos del viento en lo alto de una cofa; para ese crepitar desenfrenado que promete mucha ventolera de aguas, mucho cabello en desorden y mucha hazaña heroica en los mares esplendorosos de mi tierra. ${ }^{17}$

Al enfrentar por mar a la isla de Calbuco, que en muchos sentidos es como una introducción a Chiloé, Subercaseaux otea distraídamente la costa y los botes que regresan a puerto de las faenas de pesca.

Pero luego observamos algo muy extraño: en ellos no va ningún hombre; todas son mujeres. Robustas hembras empuñan valientemente el remo mientras algún perro, siempre de aspecto inverosímil, ladra interminablemente en la proa, como queriendo proteger a esas terribles vírgenes del mar. Las centollas rojizas, los verdosos y espinudos erizos, los negros choros brillan en el fondo de las embarcaciones. Alguna de estas mujeres alza un instante la cabeza y sonríe, luego levanta su cabellera con un rápido revés de mano y vuelve a remar con una furia cada vez renovada. Ya no les importa el barco que las dejó atrás. Su vida está ahí, en el botín precioso que es la razón única de su existencia. ${ }^{18}$

Y en párrafo seguido, concluye:

\footnotetext{
${ }^{17}$ Ibídem, 159.

${ }^{18}$ Ibídem, 236.
} 
Es una extraña raza ésta de los chilotes (ya son chilotes en esta parte). Las mujeres se contentan con una casita y un cercado con unas pocas legumbres. El dinero les sirve solamente para comprar el vestido y los utensilios domésticos. Así, pues, son muy pobres en estas cosas, y muy ricas en otras: en el alimento que les procura el mar, y en la libertad maravillosa que les permite no depender de nadie, ni siquiera de los hombres. ${ }^{19}$

\section{PIRATAS HOLANDESES CON DESCENDENCIA CHILOTA}

Pocos escritores chilenos amaron tanto, ni dedicaron tantas páginas inolvidables al mar como Benjamín Subercaseaux. Tal vez Francisco Coloane, el gran narrador chilote, sea el que más se le parezca en cuanto a intensidad, profundidad y comprensión del universo oceánico. $\mathrm{Cu}-$ riosamente, ambos recibieron el Premio Nacional de Literatura consecutivamente: Subercaseaux en 1963, Coloane, al año siguiente. Ambos, además, fueron buenos navegantes y leyeron con fruición los reportes de los marineros que, siglos atrás, recalaron en Chiloé y dejaron para la posteridad un sorprendente retrato del pasado isleño. Entre ellos, hay dos que a mí me parecen fascinantes: el viaje de la expedición Brouwer y el naufragio de la fragata Wager.

A principios de mayo de 1643 arribó a Chiloé una escuadra de cinco buques holandeses que pretendían pactar con "los chileses" —nombre que el cronista les dio a los chilotes - algún tipo de alianza para debilitar el dominio de la corona española en los mares australes. El comandante de la expedición, Henry Brouwer, que a la fecha era nada menos que uno de los directores de la Compañía de las Indias Occidentales de Holanda, había propiciado el viaje con especial entusiasmo, sin sospechar, claro está, que dejaría sus huesos en aquellas latitudes a causa de una "larga enfermedad" de la que no existen mayores detalles. Se sabe, sin embargo, que el último deseo de Brouwer "fue que su cuerpo se enterrase en Valdivia; y en esa virtud se le extrajeron las entrañas y se sepultaron el 15, cerca de la bahía de Brouwer [Golfo de Ancud], y se embalsamó el cadáver para ser transportado a Valdivia". ${ }^{20}$ Si bien

${ }^{19}$ Subercaseaux, Una loca geografía, 236.

${ }^{20}$ José Toribio Medina, Opúsculos varios. Tomo III (Santiago: Imprenta Universitaria, 1928), 103-04. 
los acercamientos entre los navegantes y los indígenas no fructificaron como para articular un pacto permanente (tampoco existía en la zona el oro que los ávidos holandeses anhelaban encontrar), la bitácora de la correría ofrece una buena cantidad de datos atrayentes sobre el archipiélago y su gente. Como el de aquel cacique que, muy suelto de cuerpo, se presentó ante los corsarios cargando en una mano la cabeza de un español, "a quien había dado muerte como hacía catorce días, cuyo olor resultó sumamente desagradable para nosotros". 21

En cuanto a la rudeza del clima, asunto de vida o muerte para el navegante chilote, se menciona una tempestad aterradora ocurrida ocho años antes de la llegada de los extranjeros, en 1635: el vendaval bramó por cuarenta días seguidos, "con tal furia que estremecía la tierra y las montañas y derribaba cantidad de árboles de raíz". ${ }^{22}$ Otro apunte curioso guarda relación con las chilotas, modelos de laboriosidad y heroínas del posparto según apunta el testigo: "A pesar de que sus trajes no son a propósito para la frialdad del clima, gozan, por lo general, de excelente salud, de que hicimos frecuente experiencia a bordo, al ver que en ocasiones sus mujeres continuaban en sus ordinarias ocupaciones media hora después de haber desembarazado, cargando a sus chicuelos a la espalda; sus pechos son tan alargados, que pueden dar de mamar a sus hijos echados a la espalda. Rara vez se les ve ociosas, ocupadas constantemente en tejer los géneros para sus trajes". ${ }^{23}$ Hoy por hoy, especialmente en las islas de Mechuque y Buta Chauques, no es raro oír que los pelirrojos del lugar, que sí los hay, son descendientes de los corsarios de la expedición Brouwer.

El 6 de junio los holandeses pisaron Castro, asentamiento al "que entraron sin resistencia, habiendo huido todos sus habitantes, después de incendiar muchas de sus casas, destechado las iglesias y llevándose sus ornamentos con todos sus mejores enseres y utensilios domésticos para ocultarse en los bosques". ${ }^{24}$ Pese a la destrucción, la majestuosidad del entorno no escapó a la mirada del escribano: "La ciudad de Castro estuvo ubicada en un sitio magnífico, poblada de edificios sólidos, pero se halla ahora desolada; está situada en lo alto de un cerro con vistas

\footnotetext{
${ }^{21}$ Ibídem, 103.

${ }^{22}$ Ibídem.

${ }^{23}$ Ibídem, 109.

${ }^{24}$ Ibídem, 94.
} 
deliciosas, rodeada de arboledas frutales de toda especie y con muchas hermosas vertientes; los campos de sus alrededores están muy bien cultivados, y al tiempo de nuestra llegada los frutos de la tierra se hallaban en su mayor parte todavía en el campo". ${ }^{25}$ Entre éstos, hubo uno que llamó la atención del cronista: el cáñamo o cannabis. Lamentablemente, no da más detalles al respecto.

Los invasores se hartaron de comer las manzanas que desde entonces se dan tan bien en la Isla Grande y quedaron muy sorprendidos con el guanaco:

Refieren los españoles, que, entre otras cualidades peculiares a las ovejas del Perú, es muy notable la de que pueden cargar con facilidad desde 50 hasta 75 libras, tal como lo hacen los camellos, a los que se asemejan bastante en su aspecto, excepto que carecen de gibas en el dorso. Son capaces (si ha de creerse a los españoles) de transportar a un hombre por espacio de cuatro o cinco leguas al día. Cuando se cansan, se echan al suelo, y no habrá forma de hacerlas levantarse con golpes o de cualquier otra manera, sino que hay que descargarlas. Si sus conductores pretenden obligarlas por golpes o de otro modo a que carguen más de lo que pueden, vuelven la cabeza y los escupen en la cara. ${ }^{26}$

Respecto del oro que esperaban encontrar en Chiloé, el reporte rezuma decepción. El testimonio que sigue corresponde a lo informado por un prisionero español:

Añadió igualmente que por entonces no era posible hallar oro o plata en Chiloé, si bien en años pasados se había extraído alguna cantidad de estos metales en sus minas; que desde el año 1633 esa extracción cesó por completo, a causa de una violenta epidemia que causó la muerte por lo menos de una tercera parte de sus habitantes, y que el resto, no encontrando la compensación suficiente en el trabajo de las minas, se había aplicado al abono y cultivo de sus tierras; de tal modo, que de tiempo atrás no se veía oro o plata acuñados o en polvo entre los españoles de allí; y si se les preguntaba por alguno de estos metales, su respuesta era que debían ir a buscarlos a Osorno y Valdivia [desafío que

${ }^{25}$ Medina, Opúsculos varios, 95.

${ }^{26}$ Ibídem, 94. 
por supuesto los holandeses emprendieron], donde los había en abundancia; que, a esta causa, su comercio lo hacían por canjes, y así los buques que cada año iban de Concepción y Santiago (que eran sólo en número de tres) con paños de lana o hilo, vino, pimienta y hierro, llevaban de retorno frazadas, tablas, cáñamo, lino y otras cosas por el estilo. Las tablas las acarreaban de las montañas distantes siete $\mathrm{u}$ ocho leguas del mar, donde las labraban a fuerza de hacha solamente, sin sierras, no sin gran demora e increíble trabajo, productos que por entonces tenían poca o ninguna estima. ${ }^{27}$

\section{EL ABUELO DE LORD BYRON RESUCITA EN CHILOÉ}

Casi un siglo después de las correrías de los holandeses por Chiloé, un día 14 de mayo de 1741, el abuelo de Lord Byron naufragó a la edad de diecisiete años en el archipiélago Guayaneco, esto es, al sur del Golfo de Penas, a más de quinientos kilómetros del extremo meridional de la Isla Grande. Byron tripulaba en calidad de cadete la fragata Wager, miembro de una infausta expedición que, al mando de Lord Anson, pretendía asolar las posesiones de la corona española en las costas del Pacífico. Cinco años tardó el mozalbete en regresar a Inglaterra tras el desastre. Y dedicó extenuantes meses a huir, literalmente a remos, del páramo en donde zozobró la embarcación. Las pellejerías que soportó junto a otros tres supervivientes superan en espanto y miseria a cualquier versión novelada de la realidad. Bien lo sé, pues hace algún tiempo traduje el documento en que John Byron narró detalladamente la escalofriante experiencia. El título del libro, publicado en 1768, resulta en extremo fatigoso, mas el contenido es notable: Relato del Honorable John Byron (Comodoro de la última expedición alrededor del mundo) que contiene una exposición de las grandes penurias sufridas por él y sus compañeros en la costa de la Patagonia desde el año 1740 hasta su arribo a Inglaterra en 1746, con una descripción de Santiago de Chile $y$ de las usanzas y costumbres de sus habitantes y además una relación de la pérdida de la fragata Wager, de la escuadra del almirante Anson. Enfrentado a este verdadero trabalenguas dieciochesco, espero haber

${ }^{27}$ Ibídem, 100. 
dado con una solución amistosa: La pérdida de la fragata Wager. Naufragio y supervivencia en la Patagonia.

Arribar a Chiloé implicó para Byron algo más que salvar el pellejo y dar por terminadas las infamantes estrecheces que había pasado a lo largo de meses. La última tormenta antes de llegar a la Isla Grande fue especialmente tortuosa, mas los náufragos, a bordo de una improbable cáscara de nuez, percibían que de pisar tierra su suerte cambiaría para siempre. No se equivocaron:

Mantuvimos la canoa alejada del peligro hasta que llegamos a aguas tranquilas y desembarcamos en un lugar deshabitado de la isla de Chiloé. Allí permanecimos el día siguiente, bajo una fuerte nevazón, con la idea de recuperarnos un poco de la fatiga. Pero el frío era tan endemoniado que, al no tener zapatos ni medias, creímos que perderíamos los pies. El capitán Cheap estaba en muy mal estado. Y si se hubiese visto forzado avanzar algunas pocas leguas más sin descanso, no lo habría soportado. Quiso entonces Dios que, en buena medida, nuestros sufrimientos se acercaran a su fin. ${ }^{28}$

Byron vuelve a tomar contacto con la civilización - el desprecio y mal agradecimiento que demuestra por los chonos es notorio: "bestiales" 29 los llama, pese a que, a la postre, fueron ellos los que evitaron que sus nobles huesos se hicieran polvo en aquellos confines- y vuelve a confiar en la especie humana. La hospitalidad de los chilotes tuvo mucho que ver con eso.

Las observaciones que dejó Byron para la posteridad ofrecen diversos grados de interés, dependiendo, por supuesto, de quién sea el que las lee. Sus apreciaciones pueden ir desde lo pintoresco, pasando por lo ingenuo, hasta llegar a lo indiscutiblemente valioso. No obstante, en cualquiera de estas tres categorías, las revelaciones de Byron vienen a refrescar la admonición de Subercaseaux en cuanto a que los chilenos sabemos poco o nada sobre Chiloé. Existe, además, una curiosa concordancia entre ambos autores: los chilotes les parecieron bellos, algo en lo que los chilenos, aparentemente, no hemos reparado con especial en-

${ }^{28}$ John Byron, La pérdida de la fragata Wager (Santiago: Ediciones Universidad Diego Portales, 2017), 121.

${ }^{29}$ Ibídem, 124. 
tusiasmo hasta el día de hoy. "Son personas fuertes y bien constituidas, de rasgos extremadamente hermosos, tanto hombres como mujeres, y sumamente pulcras", ${ }^{30}$ sostuvo Byron.

A los pocos días de su llegada a la isla, los indios despacharon un mensajero a Castro para que informase al corregidor español de la presencia de los ingleses. Tres jornadas después,

el hombre regresó con una orden dirigida a los caciques principales: debíamos ser conducidos directamente a cierto lugar en donde habría una patrulla de soldados esperándonos. Los pobres indios demostraron una gran preocupación por nosotros al oír del mensajero los preparativos que se efectuaban para recibirnos, ya que les tenían pavor a los soldados españoles. Se manifestaron ansiosos por saber a qué país pertenecíamos. Les dijimos que éramos ingleses y que estábamos en guerra con España, ante lo cual se sintieron más encariñados que nunca con nosotros. Estoy seguro que, de haberse atrevido, nos habrían ocultado entre ellos para evitar así que enfrentásemos algún peligro. Tan lejos están de representar algo para España, que detestan el mismísimo apelativo de español. Y, bueno, esto no me sorprende: se les mantiene bajo tal nivel de sometimiento, bajo tal laboriosa esclavitud a fuerza de abusos y castigos, que me parece la cosa más absurda del mundo que los españoles pudieran confiar en la ayuda de esa gente cuando alguna emergencia así lo requiriese. ${ }^{31}$

A punto de llevarse a cabo el traslado, ocurre una situación con innegables ribetes de picaresca. Proveniente de Castro, se presenta ante los tres ingleses un cura jesuita. Al sacerdote no lo mueven la compasión ni la curiosidad ni el destino de aquellas almas impías: "La primera cosa que el buen padre hizo fue extraer de su bolsillo una botella de brandy y darnos un trago, con el propósito de abrir nuestros corazones. Hecho eso, fue de inmediato al meollo del asunto y preguntó si habíamos rescatado relojes o anillos del naufragio". ${ }^{32}$ El capitán Cheap logra ocultarle al jesuita su reloj de repetición de minutos de oro, pero, un tanto abusivamente, insta al subordinado Campbell para que entregue

\footnotetext{
${ }^{30}$ Ibídem.

${ }^{31}$ Ibídem, 125.

${ }^{32}$ Ibídem, 126.
} 
un reloj de plata. "Campbell accedió a regañadientes y poco después recibió a cambio un regalo miserable del padre, que no valía ni un cuarto de la montura del reloj". ${ }^{33}$ El episodio llegó más tarde a oídos del gobernador, "quien se mostró sumamente ofendido, pues suponía que si alguno de estos objetos le correspondían a alguien, era a él. Y no perdonó a los jesuitas". ${ }^{34}$

Una vez en Castro, la tercera ciudad más antigua de lo que tiempo después llegaría a ser Chile, Byron repara en varias situaciones que dan para recomponer, en la medida en que la distancia lo permite, ciertos aspectos de la vida diaria que por entonces se llevaba en el principal asentamiento de Chiloé. En cuanto a los vecinos en general, el inglés asegura que eran "personas caritativas y bondadosas, aunque muy ignorantes y totalmente gobernadas por los frailes, que les hacen creer lo que a ellos les conviene". ${ }^{35}$ Un asunto a todas luces desconcertante es que, según el cronista, la lingua franca no era el castellano, sino la lengua de los indios. Incluso los españoles la preferían a la castiza, pues "decían que la encontraban más hermosa que la propia". ${ }^{36}$

Las mujeres nunca dejan de ser bellas para Byron. Y en este caso específico, al no tratarse ya de indias puras, sino de criollas o mestizas, sus apreciaciones tienden a ser más detallistas:

(...) tenían rostros finos, varias de ellas eran muy hermosas; gozaban de buena voz y podían improvisar un poco acompañadas de una guitarra, pero también tenían la fea costumbre de fumar tabaco, que allá era un producto escaso y, por lo mismo, se consideraba un gran agasajo cuando se reunían. La dueña de casa se presentaba con una enorme pipa de madera atiborrada de tabaco, $\mathrm{y}$, tras aplicarle dos o tres bocanadas enérgicas, metía la cabeza bajo su capa para que no escapase el humo, y entonces aspiraba. Transcurrido un instante, se veía el humo salir por su nariz y sus orejas. A continuación le entregaba la pipa a la dama siguiente, quien hacía otro tanto hasta que ésta circulaba por todas las concurrentes. ${ }^{37}$

\footnotetext{
${ }^{33}$ Byron, La pérdida, 127.

${ }^{34}$ Ibídem, 127.

${ }^{35}$ Ibídem, 133.

${ }^{36}$ Ibídem.

${ }^{37}$ Ibídem, 133-34.
} 
Hubo ocasiones, sin embargo, en que las beldades de la zona decepcionaron a nuestro atento observador:

Las mujeres de mejor posición rara vez llevaban zapatos o medias en casa, reservando su uso sólo para ocasiones particulares. Con frecuencia las veía ir a la iglesia, que se alzaba frente a la casa del gobernador, caminando a pie pelado por el barro y el agua; en la puerta del templo se ponían las medias y los zapatos; al salir, volvían a quitárselos. Aunque por lo general eran guapas y tenían una complexión hermosa, varias de ellas se maquillaban de forma tan ridícula que, al verlas, resultaba imposible no reírse en sus caras. ${ }^{38}$

"Las mejores papas del mundo", en el decir del náufrago, se preparaban de la siguiente manera: "siempre las asaban en un rescoldo, luego las raspaban y las servían durante las comidas en lugar de pan". ${ }^{39}$ En cuanto al comercio de otros productos, Byron destaca el oficio demostrado por los lugareños en la crianza de cerdos. Al parecer, se distinguían en ello, puesto que proveían a Chile y Perú de jamones. Otros bienes de la economía local: manteca de chancho, tablones de cedro, "cofrecitos tallados que las damas españolas requieren para guardar su labor", 40 alfombras, colchas y ponchos "finamente bordados. Estos últimos los utilizan en Chile y Perú para cabalgar, tanto la gente de sociedad como la de origen modesto, pues se estima que son mucho más adecuados para el jinete que cualquier otro tipo de prenda". ${ }^{41}$

Byron también da cuenta de una institución de la época que los lugareños llamaban "el barco anual de Lima":

Los isleños nunca esperaban que llegara más de uno al año, aunque a veces sucedió que arribaron dos en ese lapso, y en otras ocasiones transcurrieron dos o tres años sin tener noticias de él. Cuando esto último sucedía, la gente se angustiaba bastante, pues el barco les traía trapos, telas, linos, sombreros, cintas, tabaco, azúcar, brandy y vino, mas éste se destinaba mayoritariamente al uso de las iglesias. El mate, una hierba de Paraguay que se utiliza en toda Sudamérica en vez de té, también era un artículo indis-

\footnotetext{
${ }^{38}$ Ibídem, 141.

${ }^{39}$ Ibídem, 134.

${ }^{40}$ Ibídem.

${ }^{41}$ Ibídem, 134-35.
} 
pensable. La carga venía consignada principalmente a los jesuitas, quienes empleaban a más indios que todos los demás habitantes juntos $\mathrm{y}$, evidentemente, concentraban el grueso del comercio. No existía el uso del dinero en la isla. Si alguien deseaba algunas yardas de lino, un poco de azúcar, de tabaco, o de cualquier otro bien proveniente de Perú, entregaba a cambio tantos tablones de cedro, tantos jamones o tantos ponchos. ${ }^{42}$

Pudibundo y cuidadoso, sin soltar nombres, Byron anota que frecuentó la casa de un viejo sacerdote, "considerado uno de los hombres más ricos de la isla". ${ }^{43} \mathrm{El}$ venerable anciano tenía una sobrina, quien habría de heredar toda su riqueza. Gracias a los esfuerzos y desvelos del tío, la joven era un dechado de buena educación "y se le reconocía como una de las señoritas más preparadas de Chiloé". 44 No obstante, Byron se ve en la obligación de precisar que la muchacha "era una buena persona, mas no podía decirse que fuera hermosa". ${ }^{45}$ Pero la encerrona ya estaba en marcha:

La joven me concedió el honor de fijarse en mí mucho más de lo que yo merecía, y le propuso al tío convertirme y luego le rogó su consentimiento para casarse conmigo. Como el viejo sentía adoración por ella, accedió de buena gana y, en mi siguiente visita, me informó de la propuesta de la joven y de su aprobación, conduciéndome al mismo tiempo a un cuarto en donde había varios baúles y cómodas, que procedió a abrir, enseñándome, primero, la gran cantidad de ropa elegante que poseía su sobrina, y luego, su propio vestuario, añadiendo que sería mío cuando él muriese. Entre otras cosas, me mostró una pieza de lino, de la cual, dijo, debían cortarse de inmediato camisas para mí. Reconozco que este último ítem me produjo una tentación enorme. Sin embargo, ya había resuelto declinar la oferta y pronuncié las mejores excusas que pude para no aceptar el honor que me concedían, pues a esa altura hablaba suficiente español como para darme a entender. ${ }^{46}$

\footnotetext{
42 Byron, La pérdida, 135.

${ }^{43}$ Ibídem, 137.

${ }^{44}$ Ibídem, 137-38.

45 Ibídem, 138.

${ }^{46}$ Ibídem.
} 


\section{EL CURA QUE VENDIÓ A PRECIO DE ORO SUS IMÁGENES SANTAS}

En el año 2000, la Unesco declaró que dieciséis iglesias chilotas contaban con los atributos necesarios para ser consideradas como parte del patrimonio de la humanidad. Contrariamente a lo que la gran mayoría de los chilenos piensa, los templos no son en rigor una muestra de la devoción católica de los isleños, sino, más bien, un símbolo enmaderado de un sincretismo religioso bastante desconocido que en su momento contó incluso con la complicidad de algunos de los sacerdotes que ayudaron a edificarlos. Transcurridos los años, sin embargo, hubo momentos durante el siglo XIX en que la fe popular chocó abiertamente con la visión hegemónica de la alta jerarquía eclesiástica, y la tradición que hoy celebran tanto los nativos como los turistas y los expertos de la Unesco estuvo a punto de desaparecer.

En sí, las iglesias chilotas se remontan a los siglos XVII y XVIII, y tal vez sería justo partir mencionando el tema bajo la siguiente admonición: no todos los jesuitas radicados en Chiloé fueron de la misma catadura que el cura codicioso descrito por Byron, aquel que intentó rapiñar las únicas pertenencias de valor que habían logrado mantener consigo los náufragos. Los jesuitas llevaban casi un siglo dedicados a la evangelización del archipiélago al momento en que el inglés llegó a la Isla Grande. Y según Alberto Trivero, ${ }^{47}$ autor de Fray Hilario Martínez: Siguiendo las huellas de su santería, los discípulos de Ignacio de Loyola no sólo se concentraron en el "proselitismo cristiano". ${ }^{48}$ Por

${ }^{47}$ Alberto Trivero Rivera nació en Torino el año 1946. Italiano de nacimiento, pero de origen chileno, el autor relata en el prólogo de Fray Hilario Martínez lo siguiente: "Aprendí a amar la santería chilota desde que me fui a vivir a Chiloé, en 1970. // El episodio más impactante se dio en febrero de 1974. Cuando la junta militar subió al poder, yo enseñaba en la escuela rural de Achao. Apenas se reanudaron las clases, después de la suspensión que hubo, un encargado del jefe de plaza reunió a todos los profesores y nos pidieron una declaración de apoyo incondicionado al régimen militar. Yo me negué, alegando que siendo italiano la ley chilena me prohibía entrometerme en un aspecto de política nacional. Creía haber sido lo suficientemente diplomático, pero no fue así: inmediatamente me apartaron de la escuela y a los pocos días me detuvieron. Fue la primera detención de otras que se repitieron, hasta que algunos carabineros que me tenían aprecio y simpatía me avisaron que era mejor que me 'echara el pollo lo más pronto', pues el jefe de plaza, el teniente Rastrillo, me la tenía jurada”.

${ }^{48}$ Alberto Trivero Rivera, Fray Hilario Martínez: Siguiendo las huellas de su santería (Santiago: Ediciones Tácitas, 2016), 14. 
medio de las llamadas "misiones circulares", dos jesuitas recorrían cada año todos los rincones del archipiélago a bordo de una dalca inestable. Con ellos llevaban "su preciada santería" ${ }^{49}$ pero también administraban "el apoyo social, la medicina, la educación, el cariño". ${ }^{50}$ La misión evangelizadora, insiste el autor, no era el único objetivo de las misiones circulares. "A éstas, se asociaba la voluntad de socorrer a poblaciones humildes, acosadas por la alevosía de los encomenderos, por un lado, y por la pobreza y las enfermedades por otro". 51

El origen de las magníficas iglesias chilotas que hoy son patrimonio de la humanidad, nos informa Trivero, fue bastante modesto:

Hasta bien entrado el siglo XVIII, las capillas misionales eran simples rucas pajizas, a menudo embellecidas por alguna imagen sagrada de madera, obra rústica pero fascinadora de algún misionero o de algún humilde isleño. Sí, porque los jesuitas veían en la imaginería sagrada un instrumento de evangelización particularmente apreciado por la población indígena. De allí el esfuerzo de distribuir en todas las capillas del archipiélago la santería, lo cual hicieron, inicialmente, trayendo unas pocas imágenes de Perú y de España, y sucesivamente labrando ellos mismos las imágenes y enseñándoles a los artesanos este magnífico arte. Así dieron comienzo a la escuela de santería chilota, de tal forma que, finalmente, casi cada capilla misional tenía la imagen de su santo patrono y también otras que lo acompañaban. ${ }^{52}$

Luego de que los jesuitas fuesen expulsados del reino español en 1767, los encargados de continuar con la distintiva evangelización de los isleños fueron los franciscanos. Y entre ellos nadie cumplió la labor con tanto ahínco como fray Hilario Martínez, un gallego singular: fue misionero en Tahití, se retiró de la orden franciscana, volvió a ella y se estableció en Calbuco el año 1771. Martínez, que con el correr del tiempo construyó cinco capillas en el archipiélago, "traía consigo una colección de imágenes sagradas y también una niñita de cortos años, la cual era la luz de sus ojos: probablemente se trataba de una hija natural

\footnotetext{
${ }^{49}$ Trivero, Fray Hilario, 14.

${ }^{50}$ Ibídem, 14-15.

51 Ibídem, 15.

52 Ibídem, 15-16.
} 
que el respeto hacia su memoria convertiría en una hija adoptiva". ${ }^{53}$ En 1777 se radicó en Tenaún, en donde edificó una iglesia. Pero a los pocos meses de su llegada, "su hijita le fue arrebatada y luego apareció muerta". 54

Evidentemente, al cura le sobraban razones para largarse del lugar tras el homicidio, y así lo hizo. Invitado por los Cinco Pueblos - una comunidad indígena formada por los habitantes de las islas de Caguach, Apiao, Alao, Chaulines y Tac-, Martínez se instaló en Caguach. Y, claro, en más de un sentido había dado en el clavo al huir despavorido de Tenaún: el tino del sacerdote, que estaba al tanto de los elementos en juego al momento de tomar su decisión, fue haber elegido con sumo cuidado el emplazamiento del templo que, con el correr de los años, llegaría a cobrar una importancia crucial en la religiosidad pagana del archipiélago:

(...) cuando fray Hilario se establece en Caguach e inserta en el nguillatún ${ }^{55}$ la celebración del Nazareno, logra dos objetivos a la vez: aprovechar la importancia de Caguach en cuanto isla donde se celebraba el más importante de los nguillatún, para rápidamente asegurar a la devoción hacia el Nazareno una acogida generalizada entre los Cinco Pueblos, y probablemente en toda la comarca; cristianizar aquella que parecía ser la principal celebración pagana. Su propósito fue muy acertado: el nguillatún de la Pincoya se convirtió muy rápidamente en la principal celebración de todo el Chiloé indígena, y con el tiempo, no solamente de la sociedad indígena. ${ }^{56}$

Fray Hilario vendió, a precio exorbitante, su colección de ocho imágenes a las comunidades reunidas en Caguach, que pagaron el monto en cuotas anuales entre los años 1778 y 1782. En cifras de hoy en día, la suma bordea los 125 millones de pesos, una verdadera fortuna si consideramos la pobreza de los adquirientes y que en conjunto no su-

${ }^{53}$ Ibídem, 19.

${ }^{54}$ Ibídem, 20.

${ }^{55}$ El nguillatún es una rogativa mapuche por medio de la cual se fortalece la unión de la comunidad, se agradecen las bonanzas recibidas y se solicita a los espíritus el futuro bienestar.

56 Trivero, Fray Hilario, 36-37. 
peraban las seiscientas almas. ${ }^{57}$ Según Trivero, no se sabe bien por qué el cura exigió tanto dinero, pero supone que el botín recaudado sirvió para erigir el templo caguachano y alimentar a quienes trabajaron en él. "Maravilla la extraordinaria prueba de fe y cariño que demostraron los Cinco Pueblos realizando un esfuerzo tan grande para poder dar vida a la capilla más importante de Chiloé, gracias a la cual dieciséis templos chilotes vinieron a constituirse en patrimonio de la humanidad". ${ }^{58}$ Trivero apunta al hecho de que la construcción de la iglesia de Caguach dio pie, más de 200 años después, a la distinción de la Unesco destinada a salvaguardar los dieciséis templos chilotes aludidos.

El vínculo entre el chilote y la santería, continúa Trivero, es peculiar, muy distinto al que propone la ortodoxia católica. Él observa "una relación de reciprocidad visceral y materna". ${ }^{59}$ Por una parte, al santo se le pide ayuda, y por el otro se le protege casi como a un niño, "y como a un niño se le viste" ${ }^{60}$ Cuando las celebraciones, que sin lugar a dudas rozan el paganismo, terminan en juerga, a la imagen sagrada se le voltea con la intención de que sus ojos no reparen situaciones indecorosas, como se haría con un menor de edad, pero no "por temor que el santo vea el comportamiento de los presentes o su borrachera, un comportamiento que no es estimado impropio por parte de los presentes". ${ }^{61}$

Trivero admite que esta relación visceral que desarrollaron los fieles con las imágenes es poco ortodoxa y casi herética, y que por lo mismo puede ser vista con malos ojos por parte de la jerarquía eclesiástica. Pero a la vez advierte que cualquier medida en contra de esta manifestación de fe "puede llevar a la pérdida de la identidad de la misma comunidad, y con eso al progresivo abandono de la religiosidad, que es lo que ya está ocurriendo con las nuevas generaciones". ${ }^{62}$

La fiesta del Nazareno de Caguach se lleva a cabo todos los años durante la última semana de agosto y es la celebración religiosa más importante de Chiloé. "Entender a Caguach", sostiene Trivero, "significa entender el alma mestiza de Chiloé". ${ }^{63}$ Por "alma mestiza" el inves-

\footnotetext{
${ }^{57}$ Trivero, Fray Hilario, 22.

${ }^{58}$ Ibídem, 24.

${ }^{59}$ Ibídem, 25.

${ }^{60}$ Ibídem.

${ }^{61}$ Ibídem, 26.

62 Ibídem.

${ }^{63}$ Ibídem, 31.
} 
tigador se refiere al sincretismo ocurrido entre las creencias indígenas y el pensamiento jesuítico. La amalgama, por así llamarla, se dio sin la típica sumisión, "pues los jesuitas respetaban y valoraban el pensamiento indígena, siempre que no entrara en contraste con los elementos sustanciales de la doctrina cristiana". ${ }^{64}$ En suma, el indígena se convertía al cristianismo "manteniendo y reforzando su propia identidad étnica". ${ }^{65}$ La misa y la procesión de Caguach representan "la evolución del kamarikún-nguillatún y la devoción a la santería adquiere caracteres propios que la distinguen del resto del mundo cristiano: hay un cristianismo chilote, propio de la sociedad indígena" ${ }^{66}$

En sus comienzos, a fines del siglo XVIII, la procesión se celebraba el 30 de agosto, día de Santa Rosa (los franciscanos provenían del convento de Santa Rosa de Ocopa, en Perú). Durante esa misma época del año, los mapuches acostumbraban a poner en marcha un nguillatún importante, "para festejar la llegada de la primavera, pedirle a la Divinidad abundancia de frutos y combinar matrimonios entre familias aliadas pero de islas diferentes, para respetar la tradición exogámica propia de su cultura. Hasta la actualidad la procesión del Nazareno mantiene muchos de los elementos propios del nguillatún: y no se trata de elementos marginales, sino sustanciales". ${ }^{67}$ Trivero afirma que fue la procesión del Nazareno la que se insertó en la celebración del nguillatún, y no al revés, recibiendo así un aura cristiana que antes no tenía. "Se trataba, evidentemente, de un nguillatún de gran importancia, que acomunaba a los Cinco Pueblos los cuales ya entonces le reconocían al rewe de Caguach una centralidad devocional común". ${ }^{68}$ El rewe, vale recordarlo, es la explanada sagrada en donde se desarrolla el nguillatún. En la Colonia casi todas las capillas chilotas fueron edificadas a un costado del rewe, para mantener y recalcar el carácter sagrado del lugar, convirtiéndolo a la cristiandad.

Tres décadas después de la expulsión de los jesuitas, los franciscanos habían duplicado en número los ochenta templos que dejó en pie la orden proscrita. Al mismo tiempo, estimularon una escuela autóctona dedicada a la construcción de imágenes sagradas.

\footnotetext{
${ }^{64}$ Ibídem.

${ }^{65}$ Ibídem.

${ }^{66}$ Ibídem, 31.

${ }^{67}$ Ibídem, 34.

${ }^{68}$ Ibídem.
} 
Pero hacia mediados del siglo XIX, la imaginería chilota estuvo a punto de ser destruida por la jerarquía eclesiástica, que se oponía a las fiestas patronales. El obispado habló de "orgías", "bacanales", "bailes de enmascarados", ceremonias en las que "se desahogan pasiones innobles recitando romances y haciendo descripciones siempre satíricas e injuriosas" ${ }^{69}$ Décadas después, en 1886, el obispo Molina era partidario de eliminar todas las fiestas populares de Chiloé y excomulgar a los curas que las permitiesen o acudiesen a ellas. En una circular dirigida a los párrocos, sostuvo que no se trataba de encuentros religiosos, sino "en sentido pagano", dado que "las reuniones con mezcla de los dos sexos de todas edades, día y noche, con excesos de comida y bebida dan por resultado la embriaguez, la impureza". ${ }^{70}$ En 1889 la furia del obispo alcanzó a la festividad de Caguach, "donde la concurrencia era mayor y los deslices continuaban presentes". ${ }^{71}$

En palabras de Trivero,

más que el aspecto estético de la santería chilota, preocupa a la Iglesia católica la forma casi idólatra que caracteriza la devoción misma hacia algunas imágenes particulares, llamadas "los poderosos", a las cuales la fe popular atribuía poderes milagrosos. Un poder propio de la imagen en cuanto tal, y no de la virgen o el santo representado por aquella imagen. De allí que el Sínodo ${ }^{72}$ decretó que había que alejar de las capillas y destruir todas aquellas imágenes "indecentes y notablemente imperfectas y defectuosas, [que] lejos de excitar la devoción y veneración de los fieles hacia los santos que representan obran efectos contrarios".73

En consecuencia, decenas de imágenes fueron destruidas, particularmente en las iglesias en las que había presencia de sacerdotes. En otras ocasiones, los fieles las protegieron trasladándolas a sus propios hogares. Otro asunto jugó en contra de esta "furia iconoclasta": 74 las capillas eran propiedad de las comunidades, lo mismo que el contenido de

\footnotetext{
${ }^{69}$ Trivero, Fray Hilario, 46.

${ }^{70}$ Ibídem, 47.

${ }^{71}$ Ibídem.

72 "En 1851, se celebró en Ancud, hace pocos años erigida en diócesis (1845), el primer Sínodo Diocesano de Chile". Trivero, Fray Hilario, 46.

73 Ibídem, 48.

${ }^{74}$ Ibídem.
} 
ellas, puesto que habían sido edificadas por éstas, sin ayuda externa. No obstante, según sostiene Renato Cárdenas en Patrimonio Cultural, "muchas iglesias de campo se quedaron sin sus poderosos y con ello terminaron las celebraciones votivas, y solamente aquellas comunidades que impidieron este atropello mantuvieron hasta hoy sus representaciones y sus fiestas patronales". ${ }^{75}$

\section{JOSÉ MANUEL DE MORALEDA DESAFÍA A LOS BRUJOS LOCALES}

Las creencias espirituales de los isleños no se vieron únicamente estimuladas por el peculiar sincretismo que describe y defiende Trivero. En el libro Juicio a los brujos de Chiloé, Marino y Osorio refieren no sólo a la brujería y a su evolución en el archipiélago, sino que despliegan un panorama antropológico que en resumidas cuentas expone las particularidades del pensamiento mágico del chilote y contrapone su legitimidad e importancia ante cualquier enfoque folclorizante o globalizante. En la edición revisada de su estudio, sin embargo, los investigadores vuelven a preguntarse, tal vez con cierto ánimo derrotista, "si nuestra decisión inicial de hablar de los mitos y la magia de Chiloé había favorecido a la comprensión de la cultura popular del archipiélago o a la cultura dominante que usufructúa y reacomoda la realidad para justificar su propia dominación". ${ }^{76}$

Marino y Osorio sostienen que la brujería de Chiloé tuvo tres fases sucesivas:

La primera, caracterizada por una fusión de los sistemas mágicos provenientes de los pueblos precolombinos (chono y huilliche) del archipiélago y aquellos introducidos por los conquistadores españoles. Etapa en la cual se recrea y potencia la brujería. Una segunda etapa (siglo XIX), en la cual se fortalece y consolida dicho sistema con un fuerte nivel de intervención político-social que altera seriamente "el orden político-institucional" establecido principalmente desde el Estado republicano. Es la etapa en la cual la brujería chilota adquiere un carácter público sin precedentes y con insospechadas consecuencias. Por último, tras un enfren-

\footnotetext{
${ }^{75}$ Citado en Trivero, Fray Hilario, 48.

${ }^{76}$ Marino y Osorio, Juicio a los brujos, 18.
} 
tamiento sociopolítico con el poder político oficial (proceso judicial a la brujería), se origina una nueva etapa (y estrategia) caracterizada por la clandestinidad en el funcionamiento de este sistema, aunque manteniendo su presencia en el pensamiento y la acción de la población isleña. ${ }^{77}$

El año 1880 fue clave en esta historia: el intendente de la provincia de Chiloé, Luis Martiniano Rodríguez, las emprende judicialmente en contra de los miembros de la Recta Provincia, una organización dedicada a la brujería. Entre los antecedentes y datos que se conservan del proceso hay un total de nueve declaraciones de los acusados. También existen documentos internos de la entidad y fragmentos de algunas transcripciones del juicio aparecidas en la prensa de la época. El proceso, aunque colectivo e institucional, se realizó a través de causas particulares, con sumarios a cada uno de los imputados. ${ }^{78} \mathrm{Y}$, entre ellos, destaca el de Mateo Coñoecar Coñoecar, puesto que es a partir de éste que Marino y Osorio distinguen una "transculturación" que se retrae a un siglo antes, específicamente al año 1786, que fue cuando el navegante español José Manuel de Moraleda arribó a Chiloé con la intención de cartografiar el archipiélago y las costas patagónicas.

Coñoecar declaró lo siguiente:

"Que por la tradición y por habérselo oído a su padre y otros más que ya son muertos, sabe que en un tiempo de que no tiene noticia, pero ya en la dominación española, llegó a Payos [Queilén] en un buque de sanación un individuo apellidado Moraleda con el objeto de conseguir algunos naturales para llevar a la península [España].

"No consiguió ninguno en ese lugar, por cuya causa se vino a Tenaún, donde tampoco encontró indios que lo siguieran. Ahí en ese punto se presentó Moraleda haciendo ver que era hechicero, transformándose en pescado, lobo, palomas y otros animales y mostrando con ello que por tal causa debían seguirlo los indios.

"Casualmente en el mismo punto había una llamada Chillpila, residente de Quetalco, que tenía fama de Hechicera y los mismos indios buscáronla para hacerla competir con Moraleda. Entre las varias pruebas que hizo esta, consiguió dejar en seco el buque de

${ }^{77}$ Marino y Osorio, Juicio a los brujos, 23-24.

${ }^{78}$ Ibídem, 58. 
Moraleda en el mismo punto donde se hallaba anclado y después ponerlo a flote. Moraleda con esto se dio por vencido y en señal de reconocimiento, regaló a Chillpila un libro de hechicerías para que enseñara a los demás indígenas.

"Moraleda se retiró de ahí recalando en Quicaví como de paso y dejando a este mismo lugar con el nombre de España y Lima. La Chillpila llevó el libro a Quicaví para que aprendieran los indígenas y de ahí se organizaron las asociaciones en que ahora figura el declarante.

"Cree sí, que aún antes de la llegada de Moraleda, existían brujos en Chiloé, pero la única de quien queda conocimiento por la tradición es la llamada Chillpila. Advierte también que es tradición que la fundación que hizo esta mujer no tenía un carácter perverso que se le ha llegado a dar con el tiempo, pues en el tiempo transcurrido se han ido haciendo innovaciones, como las sentencias que se expiden para dar muerte o para hacer sufrir de otro modo a las personas". ${ }^{79}$

El testimonio de Moraleda, por su parte, transcribe con lamentable precisión las nociones que siglos más tarde iban a formarse los chilenos sobre los chilotes, haciendo gala de una mentada ignorancia, de los prejuicios y de esa proverbial falta de interés en la cultura isleña:

"Los indios [de Chiloé] parecen menos malos que los chilenos, pero de estatura más corta; el carácter de estos es en general el de todos los de su casta. Así de esta América como la de setentrional, esto es inclinados a la idolatría, mui supersticiosos, disimulados, vengativos, ebrios i ociosos; sin embargo, a expensas del incesante penoso trabajo de los padres misioneros Franciscanos, relatan la doctrina cristiana tan bien o mejor que los españoles; pero tanto a los unos como a los otros no les es ella obstáculo para dejar estar imbuidos en una multitud de necias groseras supersticiones en que están, especialmente en orden a las enfermedades i demás desgracias que no son comunes; i la misma muerte, que casi siempre atribuyen los indios y muchas veces los españoles a maleficio, lo que intentan averiguar i remediar consultando a los machis (así lla-

79 "Proceso de los brujos de Chiloé", Anales Chilenos de la Historia de la Medicina 1, año II (1960): 124, 163, citado en Marino y Osorio, Juicio a los brujos, 32-33. 
man a los curanderos, supuestos adivinos), los cuales, después de muchos misteriosos ademanes, gesticulaciones ridículas, acompañados a veces de violentas contorsiones y destemplados ahullidos, hacen pronósticos de la enfermedad i su causa, dejando mui satisfecho de sus aciertos al idiota auditorio. Yo deseé presenciar una consulta de estos miserables fanáticos pretendidos adivinos, pero no lo conseguí, porque me creían a mí más machi, adivino o brujo que todos ellos y lejos de concurrir a mi deseo se ocultaban de mi vista temerosos". 80

Las investigaciones posteriores a los juicios y el análisis de relatos orales transmitidos por generaciones han ayudado a construir un conjunto de antecedentes que permiten responder, al menos en parte, preguntas fundamentales sobre el proceso de formación de la brujería, sus métodos y técnicas, y su funcionamiento organizacional. Los autores sostienen que los iniciados en la brujería deben estar relacionados previamente a ella, ya sea a través de un pariente (de sangre o político) que sea reconocido como brujo o curandero. ${ }^{81}$

La iniciación empieza con la selección de la persona que quiere ingresar (el pariente lo sugiere). Durante su aprendizaje el candidato es ayudado por un mentor en la enseñanza de los métodos y prácticas mágicas. Una vez considerado apto, es presentado a la Mayoría, máxima autoridad de la Recta Provincia. En la ceremonia de iniciación el estudiante debe superar tres pruebas. La primera es confeccionar un macuñ o chaleco para volar. ${ }^{82}$ Mateo Coñoecar se refiere a esta prenda:

"[el macuñ] es una parte de la piel de los brujos que mueren y los que quieren tenerla la sacan del panteón a la izquierda del cuerpo en dirección del pecho hacia la barriga. Esa piel la curten con ciertas yerbas y enseguida los brujos se la cuelgan con unos cordones al lado izquierdo y con ella andan de noche produciendo una luz especial que los distingue". ${ }^{83}$

${ }^{80}$ José de Moraleda, "Exploraciones de José de Moraleda" (1887), en Anuario Hidrográfico de Chile XI, 600, citado en Marino y Osorio, Juicio a los brujos, 34.

${ }^{81}$ Marino y Osorio, Juicio a los brujos, 70-71.

82 Ibídem, 71.

83 "Proceso de los brujos de Chiloé", Anales Chilenos de la Historia de la Medicina 1, año II (1960), citado en Marino y Osorio, Juicio a los brujos, 71. 
La segunda consiste en extirparse el bautismo cristiano. Esto se realiza mediante un rito donde se recibe agua desde una cascada, sobre la cabeza, durante cuarenta días. Y en la tercera prueba se debe asesinar a un pariente como muestra definitiva de desapego a la familia. ${ }^{84}$

La cueva de Quicaví, centro de operaciones de la Recta Provincia, aún no ha sido hallada (así se nos dice en Juicio a los brujos de Chiloé), aunque existen algunas versiones sobre su ubicación y características. Nuevamente debemos regresar a las palabras de Mateo Coñoecar:

"Es una casa subterránea (...) que se halla situada en una quebrada inmediata a la casa en que vivió el finado José Marimán [brujo y Rey de la Recta Provincia], de donde hay un camino para llegar a ella. De la casa donde vive Aurora Quinchén [hechicera] también distancia de cuarenta metros. Esa habitación adentro está enmaderada, tiene una mesa, cuatro sillas principales y tres bancos de madera". 85

Hoy, cualquiera que se interese por el poder del embrujo en la sociedad chilota contemporánea puede indagar al respecto. Sólo basta preguntar un poco y, más temprano que tarde, se llegará a la persona indicada. A mí no me costó mucho: me cuentan que hace cerca de sesenta años un campesino que labraba su predio en Quicaví dio con la cueva que menciona Mateo Coñoecar; me cuentan que en las noches sin luna los brujos vuelan con su macuñ y que se reúnen en aquelarres dedicados a adorar al Maligno; me cuentan que en Quiao, en la orilla norte del lago Huillinco, ciertos individuos que uno veía desde el interior de un auto caminando a la vera del camino, arribaban a destino antes que los ocupantes del vehículo, en lugares en los que por supuesto, debido al bosque tupido, no existían atajos; me cuentan que don Yayo, allá mismo, era reconocido como brujo y que tenía entierros, es decir, tesoros ocultos bajo tierra; me cuentan que quien saca a la luz un entierro muere al cabo de un año, probablemente debido a los gases mefíticos que se concentran bajo tierra; me cuentan que, en razón de esos mismos gases, a veces se generan incendios espontáneos. La propia mujer que le compró el terreno a don Yayo, que en su entorno tenía fama de avaro,

${ }^{84}$ Marino y Osorio, Juicio a los brujos, 71-72.

85 "Proceso de los brujos de Chiloé", Anales Chilenos de la Historia de la Medicina 1, año II (1960), citado en Marino y Osorio, Juicio a los brujos, 72. 
me cuenta que recibió de parte de una vecina chismosa el dato de dónde se encontraba el entierro. Una noche, dice, de regreso a su hogar, vio un calafate en llamas, justo en donde se suponía que estaba el tesoro del brujo Yayo. En opinión de Marino y Osorio, el tiempo demostró que desarticular a una determinada organización social no fue suficiente para eliminar un sistema de pensamiento y prácticas como la magia chilota. ${ }^{86}$ El tiempo también ha dejado en claro que Chiloé, como se admiraba Benjamín Subercaseaux hace casi 80 años, sigue siendo terra incognita, o un finis terrae exótico del que poco o nada nos interesa saber. EP

${ }^{86}$ Marino y Osorio, Juicio a los brujos, 54. 